\title{
EVALUASI SISTEM DAN PROSEDUR PENGELUARAN KAS BELANJA LANGSUNG PADA DINAS PERINDUSTRIAN DAN PERDAGANGAN DAERAH PROVINSI SULAWESI UTARA
}

\author{
Bella Angelina Kasakeyan ${ }^{1}$, Herman Karamoy $^{2}$, Lidia Mawikere ${ }^{2}$ \\ ${ }^{1,2}$ Jurusan Akuntansi, Fakultas Ekonomi dan Bisnis, Universitas Sam Ratulangi, Jl. Kampus Bahu, Manado, \\ 95115, Indonesia \\ ${ }^{1}$ E-mail: bellangelina85@gmail.com
}

\begin{abstract}
A successful government is a government that always provides public services by applying the character of good goverance. One of the important things to achieve the character of good governance is the evaluation of cash expenditures. Cash expenditures are used for various types of payments, one of which is direct expenditure and is very important to support the implementation of government programs that have been previously planned. Cash expenditures procedures consist of: (1) issuance of a letter of provision of funds; (2) submission of a request for payment; (3) issuance of a payment order; (4) issuance of a warrant for disbursing funds; and (5) issuance of a letter accountability. The analytical method used is descriptive analysis method. The result of the study shows that implementation of system and procedure for direct expenditure of cash expenditures at the Regional Industry and Trade Office of North Sulawesi Province was in accordance with the applicable laws and regulations. So it can be concluded that the application of the system and procedure for the direct expenditure of cash expenditure at the Regional Industry and Trade Office of North Sulawesi Province has been carried out properly and in accordance with Minister of Home Affairs Regulation number 21 of 2011.
\end{abstract}

Keywords: systems and procedures; cash expenditures; direct expenditure

\section{PENDAHULUAN}

Otonomi daerah menuntut pemerintah daerah untuk senantiasa memberikan pelayanan publik dengan menerapkan prinsip Good Governance yang diartikan sebagai kepemerintahan yang baik. Menurut Parayanti (2015), setidaknya ada tiga elemen yang menandai terciptanya kepemerintahan yang baik, yaitu transparansi, partisipasi, dan akuntabilitas. Sebagai bentuk konkrit dalam penciptaan transparansi dan akuntabilitas publik dalam pengelolaan keuangan daerah Pemerintah menerbitkan beberapa peraturan perundang-undangan yang terkait yaitu Peraturan Pemerintah Nomor 58 Tahun 2005 tentang Pengelolaan Keuangan Daerah.

Menurut Longdong (2013), kas merupakan aset yang paling lancar dalam arti paling sering berubah dan yang paling penting dalam pelaksanaan aktivitas operasional, dan sayangnya dalam penggunaannya khususnya dalam pengeluaran kas sering disalahgunakan dan mudah untuk dimanipulasi oleh orang yang tidak bertanggungjawab terhadap otorisasi kas tersebut. Kas sangat rentan terhadap adanya kecurangan, ataupun penyelewengan yang akan mengakibatkan kerugian terhadap kas negara. Pengeluaran kas sendiri merupakan komponen sumber daya yang sangat penting dalam pelaksanaan program-program yang sudah direncanakan sebelumnya oleh pemerintah, dan harus dilaksanakan secara efektif dan efisien agar tidak terjadi pemborosan anggaran. Menurut Singgima dan Pinatik (2016), pengeluaran kas digunakan untuk berbagai macam pembayaran, yang salah satunya adalah untuk belanja langsung, dimana hal tersebut bisa dikatakan dapat banyak menelan dan rawan terjadi penyelewengan. 
Guna meningkatkan pengawasan dan juga menghindari kerugian terhadap kas negara, maka disusunlah prosedur pengeluaran kasyang diatur dalam peraturan perundang-undangan yaitu dalam Peraturan Menteri Dalam Negeri (Permendagri) Nomor 13 Tahun 2006 dan perubahannya yang kedua yaitu Peraturan Menteri Dalam Negeri Nomor 21 Tahun 2011 tentang Pedoman Pengelolaan Keuangan Daerah. Namun, dalam penerapannya setiap hari pun belum bisa dipastikan apakah pemerintah daerah benar melaksanakan prosedur pengeluaran kas ini sesuai dengan yang sudah diatur dalam peraturan perundang-undangan yang berlaku.

\section{TINJAUAN PUSTAKA}

Akuntansi sektor publik. Menurut Sujarweni (2015:1), akuntansi sektor publik dapat didefinisikan sebagai aktivitas jasa yang terdiri dari mencatat, mengklasifikasikan, dan melaporkan kejadian atau transaksi ekonomi yang akhirnya akan menghasilkan suatu informasi keuangan yang akan dibutuhkan oleh pihak-pihak tertentu untuk pengambilan keputusan, yang diterapkan pada pengelolaan dana publik di lembaga-lembaga tinggi negara dan departemen-departemen dibawahnya. Mahsun (2016:7) mengungkapkan bahwa sektor publik eksis karena dibutuhkan dan keberadaannya di tengah masyarakat tidak bisa dihindarkan (inevitable).

Akuntansi pemerintahan. Menurut Sadeli (2016:6), akuntansi pemerintahan adalah akuntansi yang berkaitan dengan bidang keuangan negara dan memiliki fungsi untuk menyediakan laporan akuntansi yang bermanfaat mengenai aspek kepengurusan (business aspect) administrasi pemerintah, serta membantu manajemen dalam melaksanakan pengawasan atas pengeluaran melalui anggaran, sesuai dengan ketentuan undang-undang yang berlaku. Parayanti (2015) mengungkapkan bahwa akuntansi pemerintahan mengacu pada penerapan teori, prinsip atau standar akuntansi pada organisasi yang tidak mencari laba, khususnya pada unit organisasi pemerintahan. Akuntansi keuangan pada pemerintah menghasilkan informasi dalam bentuk laporan keuangan pemerintah. Peraturan Pemerintah Nomor 71 Tahun 2010 tentang Sistem Akuntansi Pemerintahan menyebutkan bahwa sistem akuntansi pemerintahan adalah rangkaian sistematik dari prosedur, penyelenggara, peralatan, dan elemen lain untuk mewujudkan fungsi akuntansi sejak analisis transaksi sampai dengan pelaporan keuangan di lingkungan organisasi pemerintah.

Sistem akuntansi pemerintahan daerah. Permendagri Nomor 13 tahun 2006 dan perubahannya yang kedua yaitu Permendagri Nomor 21 tahun 2011 menerangkan bahwa sistem akuntansi pemerintahan daerah meliputi serangkaian prosedur, mulai dari proses pengumpulan data, pencatatan, penggolongan, dan peringkasan atas transaksi dan/atau kejadian keuangan serta pelaporan keuangan dalam rangka pertanggungjawaban APBD yang dapat dilakukan secara manual atau menggunakan aplikasi komputer. Adapun sistem akuntansi pemerintahan daerah sekurang-kurangnya meliputi: (a) prosedur akuntansi penerimaan kas; (b) prosedur akuntansi pengeluaran kas; (c) prosedur akuntansi aset tetap/barang milik daerah; dan (d) prosedur akuntansi selain kas.

Pengelolaan Keuangan Daerah. Permendagri Nomor 21 tahun 2011 menyatakan bahwa pengelolaan keuangan daerah adalah keseluruhan kegiatan yang meliputi perencanaan, pelaksanaan, penatausahaan, pelaporan, pertanggungjawaban, dan pengawasan keuangan daerah. Mewengkang et al., 2016) menyatakan bahwa unsur yang paling penting dalam penyelenggaraan pemerintahan dan pembangunan di daerah adalah cara pengelolaan keuangan daerah secara berdaya guna dan berhasil guna.

Belanja daerah. Permendagri Nomor 21 Tahun 2011 menjelaskan bahwa belanja daerah adalah kewajiban pemerintah daerah yang diakui sebagai pengurang nilai kekayaan bersih. Belanja daerah meliputi semua pengeluaran dari rekening kas umum daerah yang mengurangi ekuitas dana, yang merupakan kewajiban daerah dalam satu tahun anggaran dan 
tidak akan diperoleh pembayarannya kembali oleh daerah. Belanja daerah dipergunakan dalam rangka mendanai pelaksanaan urusan pemerintahan yang menjadi kewenangan provinsi atau kabupaten/kota yang terdiri dari urusan wajib, urusan pilihan dan urusan yang penanganannya dalam bagian atau bidang tertentu yang dapat dilaksanakan bersama antara pemerintah dan pemerintah daerah atau antar pemerintah daerah yang ditetapkan dengan ketentuan perundang-undangan. Belanja menurut kelompok belanja terdiri dari belanja tidak langsung dan belanja langsung. Belanja tidak langsung merupakan belanja yang dianggarkan tidak terkait secara langsung dengan pelaksanaan program dan kegiatan. Belanja langsung merupakan belanja yang dianggarkan terkait secara langsung dengan pelaksanaan program dan kegiatan. Kelompok belanja langsung dari suatu kegiatan terdiri dari: Belanja pegawai, Belanja barang dan jasa, dan Belanja modal.

Sistem dan prosedur pengeluaran kas. Prosedur akuntansi pengeluaran kas pada SKPD meliputi: (a) Sub prosedur akuntansi pengeluaran kas-langsung; dan (b) Sub prosedur akuntansi pengeluaran kas-uang persediaan/ganti uang persediaan/tambahan uang persediaan. Prosedur sub sistem akuntansi pengeluaran kas terdiri dari: (a) Penerbitan Surat Penyediaan Dana (SPD); (b) Penerbitan Surat Permintaan Pembayaran (SPP); (c) Penerbitan Surat Perintah Membayar (SPM); (d) Penerbitan Surat Perintah Pencairan Dana (SP2D); dan (e) Penerbitan Surat Pertanggungjawaban (SPJ).

Pengendalian internal. Peraturan Pemerintah Nomor 60 tahun 2008 tentang Sistem Pengendalian Intern Pemerintah menerangkan bahwa sistem pengendalian intern adalah proses yang integral pada tindakan dan kegiatan yang dilakukan secara terus menerus oleh pimpinan dan seluruh pegawai untuk memberikan keyakinan memadai atas tercapainya tujuan organisasi melalui kegiatan yang efektif dan efisien, keandalan pelaporan keuangan, pengamanan aset negara, dan ketaatan terhadap peraturan perundang-undangan. Mahmudi (2016:22) mengungkapkan bahwa komponen penting yang terkait dengan sistem pengendalian intern khususnya kegiatan pengendalian antara lain: (a) sistem dan prosedur akuntansi; (b) otorisasi; (c) formulir, dokumen, dan catatan; dan (d) pemisahan tugas.

Penelitian terdahulu. Wonggo et al. (2017) menunjukkan bahwa sistem penatausahaan belanja langsung yang dilaksanakan oleh Dinas Sosial Tenaga Kerja dan Transmigrasi Kabupaten Minahasa Selatan selaku SKPD, sudah memadai dan sesuai dengan Permendagri nomor 21 tahun 2011. Polii dan Mawikere (2015) menunjukkan bahwa pelaksanaan sistem akuntansi pengeluaran kas atas uang persediaan di Dinas Pertanian dan Peternakan Provinsi Sulawesi Utara telah dilakukan sesuai dengan teori sistem akuntansi pengeluaran kas serta aturan yang ada, sudah memiliki flowchart yang baku, namun seringkali tidak dijalankan dengan baik. Lasut et al. (2017) menunjukkan bahwa pelaksanaan sistem akuntansi belanja yang diterapkan Dinas sudah sesuai dengan peraturan yang berlaku. Ointu dan Budiarso (2016) menunjukkan bahwa pelaksanaan sistem dan prosedur pengeluaran kas uang persediaan pada Dinas Pendapatan Pengelolaan Keuangan dan Aset Daerah Kabupaten Bolaang Mongondow Selatan belum efektif disebabkan tidak terpenuhinya beberapa dokumen yang dipersyaratkan, serta pengendalian internal yang tidak dijalankan dengan baik.

\section{METODE PENELITIAN}

Penelitian ini ditinjau dari pendekatan analisisnya diklasifikasikan ke dalam penelitian kualitatif, dan ditinjau dari tingkat eksplanasinya termasuk jenis penelitian deskriptif. Penelitian ini diharapkan akan memberikan pemahaman atau gambaran sistematis secara fakta tentang bagaimana penerapan sistem dan prosedur pengeluaran kas belanja langsung pada Dinas Perindustrian dan Perdagangan Daerah Provinsi Sulawesi Utara. Penelitian ini mengambil tempat di Dinas Perindustrian dan Perdagangan Daerah Provinsi Sulawesi Utara yang terletak di Jalan Tololiu Supit No. 25 Manado. 
Jenis data yang digunakan adalah data kualitatif antara lain data hasil wawancara dan juga data dokumen yang digunakan terkait dengan prosedur pengeluaran kas belanja langsung yang dilaksanakan Dinas Perindustrian dan Perdagangan Daerah Provinsi Sulawesi Utara pada tahun 2019. Sumber data yang digunakan adalah data primer, data yang dikumpulkan langsung dari Dinas Perindustrian dan Perdagangan Daerah Provinsi Sulawesi Utara berupa wawancara, dan juga data sekunder, berupa Permendagri, literatur-literatur, jurnal ilmiah serta beberapa artikel publikasi yang digunakan sebagai acuan yang dapat menunjang penelitian ini. Metode pengumpulan data dilakukan dengan cara wawancara, dokumentasi, dan studi kepustakaan.

\section{HASIL PENELITIAN DAN PEMBAHASAN}

\subsection{Hasil penelitian}

Dari hasil wawancara yang dilakukan di Dinas Perindustrian dan Perdagangan Daerah Provinsi Sulawesi Utara, prosedur pengeluaran kas untuk belanja langsung yang dilaksanakan yaitu :

1. Penerbitan Surat Penyediaan Dana (SPD). SPD dibuat oleh BUD (Bendahara umum daerah) dalam rangka manajemen kas daerah. SPD ini disiapkan setelah adanya surat permohonan SPD yang diajukan oleh SKPD. Kuasa BUD kemudian akan menganalisa DPA-SKPD yang ada dalam database dan menganalisa anggaran kas pemerintah khususnya Dinas Perindustrian dan Perdagangan Daerah Provinsi Sulawesi Utara, kemudian menyiapkan rancangan SPD dan mendistribusikan SPD kepada pengguna anggaran, setelah Pejabat Pengelola Keuangan Daerah (PPKD) meneliti rancangan SPD yang telah diajukan dan melakukan otorisasi SPD.

2. Pengajuan Surat Permintaan Pembayaran (SPP). Bendahara Pengeluaran Dinas Perindustrian dan Perdagangan Daerah Provinsi Sulawesi Utara mengajukan SPP dalam rangka pelaksanaan belanja. Prosedur Penerbitan SPP-LS adalah sebagai berikut:

a. Bendahara dan Pejabat Penatausahaan Keuangan-SKPD (PPK-SKPD) menerima SPD yang diserahkan oleh Pengguna Anggaran.

b. Pejabat Pelaksana Teknis Kegiatan (PPTK) menyiapkan dokumen SPJ atau dokumen pendukung SPP-LS untuk kemudian diserahkan kepada bendahara pengeluaran.

c. Sesuai dengan SPD yang telah diterima dan dokumen SPJ, Bendahara pengeluaran kemudian mengeluarkan dokumen SPP-LS beserta dokumen lainnya

d. SPP-LS dan dokumen lain yang telah dikeluarkan oleh bendahara pengeluaran kemudian diserahkan kepada PPK-SKPD setelah ditandatangani oleh PPTK.

e. PPK-SKPD melakukan pengujian terhadap kelengkapan dan kebenaran SPP-LS yang telah diterima. Apabila SPP-LS tersebut dinyatakan lengkap maka PPKSKPD akan membuat rancangan SPM yang kemudian akan diserahkan kepada pengguna anggaran untuk diotorisasi. Namun apabila SPP-LS dinyatakan tidak lengkap maka PPK-SKPD akan menerbitkan Surat penolakan SPM, dan menyerahkannya kepada bendahara pengeluaran untuk dilakukan penyempurnaan.

3. Penerbitan Surat Perintah Membayar (SPM). SPM diterbitkan setelah SPP telah dinyatakan lengkap dan sah, kemudian SPM ini akan diajukan kepada BUD sebagai dasar untuk penerbitan SP2D. Prosedur Penerbitan SPM adalah sebagai berikut:

a. Sesuai dengan SPD dan dokumen SPJ, Bendahara pengeluaran kemudian mengeluarkan dokumen SPP-LS beserta dokumen lainnya.

b. SPP-LS dan dokumen lain yang telah dikeluarkan oleh bendahara pengeluaran kemudian diserahkan kepada PPK-SKPD.

c. PPK-SKPD melakukan pengujian terhadap kelengkapan dan kebenaran dokumen 
SPP-LS. Apabila dinyatakan lengkap, maka PPK-SKPD akan membuatkan rancangan SPM.

d. PPK-SKPD kemudian menyerahkan rancangan SPM kepada pengguna anggaran untuk diotorisasi.

e. Apabila SPP-LS dinyatakan tidak lengkap, PPK-SKPD akan menerbitkan surat penolakan SPM.

4. Penerbitan Surat Perintah Pencairan Dana (SP2D). SP2D diterbitkan oleh BUD dalam hal ini BKAD Provinsi Sulawesi Utara, sebagai dasar untuk pencairan dana lewat kas perangkat daerah. Prosedur Penerbitan SP2D adalah sebagai berikut:

a. SPM diserahkan kepada BUD oleh Pengguna Anggaran setelah diotorisasi.

b. Setelah SPM diterima, BUD kemudian meneliti kelengkapan dokumen yang diajukan, apakah tidak melampaui pagu dan memenuhi persyaratan.

c. Apabila kelengkapan dokumen SPM telah dinyatakan lengkap, maka BUD akan menerbitkan SP2D.

d. BUD kemudian akan menyerahkan SP2D yang diterbitkan untuk keperluan pembayaran langsung kepada pihak ketiga. Namun apabila kelengkapan dokumen SPM tidak lengkap atau tidak sah ataupun pengeluarannya melampaui pagu anggaran, maka BUD menerbitkan surat penolakan penerbitan SP2D.

5. Penerbitan Surat Pertanggungjawaban (SPJ). Pada pengeluaran pembayaran beban langsung, dokumen pendukung SPP-LS dapat dipersamakan sebagai bukti pertanggungjawaban. Dokumen pendukung tersebut antara lain: nota pembelian, kwitansi, berita acara serah terima pekerjaan/barang, berita acara pemeriksaan hasil pekerjaan, dokumentasi, dan lain-lain.

\subsection{Pembahasan}

Evaluasi prosedur penerbitan SPD. SPD dibuat oleh BUD dan diotorisasi oleh PPKD dalam rangka manajemen kas daerah. Dokumen SPD menunjukkan jumlah ketersediaan dana untuk pelaksanaan kegiatan tiap-tiap SKPD dalam periode waktu tertentu. Permintaan penerbitan SPD pada Dinas Perindustrian dan Perdagangan Daerah Provinsi Sulawesi Utara dilakukan sebulan sekali sesuai jadwal kegiatan (anggaran kas). Prosedur penerbitan surat penyediaan dana yang dilaksanakan sudah sesuai dengan Permendagri Nomor 21 tahun 2011, dengan pihak-pihak yang terkait: (1) Kuasa BUD yang melaksanakan tugas menganalisa DPA-SKPD yang ada di database, menganalisa anggaran kas pemerintah daerah khususnya data SKPD Dinas Perindustrian dan Perdagangan Daerah Provinsi Sulawesi Utara, menyiapkan rancangan SPD, kemudian menyerahkannya kepada PPKD untuk diteliti dan diotorisasi; dan (2) PPKD yang kemudian bertugas untuk meneliti rancangan SPD yang diajukan oleh BUD kemudian mengotorisasi SPD, dan setelah itu mendistribusikan SPD tersebut kepada pengguna anggaran untuk dijadikan dasar dalam pembuatan SPP.

Evaluasi prosedur pengajuan SPP. SPP-LS adalah dokumen yang diajukan oleh bendahara pengeluaran untuk permintaan pembayaran langsung kepada pihak ketiga atas dasar perjanjian kontrak kerja atau surat perintah kerja lainnya. Dokumen SPP dibuat oleh bendahara pengeluaran berdasarkan SPD yang diterima dari pengguna anggaran. Prosedur pengajuan surat permintaan pembayaran yang dilaksanakan Dinas Perindustrian dan Perdagangan Daerah Provinsi Sulawesi Utara sudah sesuai dengan Permendagri nomor 21 tahun 2011, dengan pihak-pihak yang terkait: (1) PPTK yang bertugas untuk mengumpulkan dokumen-dokumen pendukung SPP-LS yang kemudian menyerahkannya kepada bendahara pengeluaran, juga menandatangani dokumen SPP-LS; (2) Bendahara pengeluaran yang melakukan tugas untuk membuat SPP dan mempersiapkan lampiran-lampirannya, kemudian mengajukannya kepada PPK-SKPD; dan (3) PPK-SKPD yang kemudian bertugas untuk 
meneliti kelengkapan dan kebenaran dokumen SPP yang diajukan oleh Bendahara pengeluaran.

Evaluasi prosedur penerbitan SPM. Dokumen SPM disiapkan oleh PPK-SKPD dan kemudian diotorisasi oleh pengguna anggaran. Dokumen SPM disiapkan oleh PPK-SKPD berdasarkan SPP yang telah dinyatakan lengkap dan sah, yaitu apabila SPP yang diajukan oleh bendahara pengeluaran tidak melebihi pagu anggaran dan didukung dengan kelengkapan dokumen yang sesuai peraturan. Prosedur penerbitan surat perintah membayar yang dilaksanakan Dinas Perindustrian dan Perdagangan Daerah Provinsi Sulawesi Utara sudah sesuai dengan Permendagri nomor 21 tahun 2011, dengan pihak-pihak yang terkait: (1) PPKSKPD yang melaksanakan tugas menguji kebenaran dan kelengkapan SPP yang diajukan oleh bendahara pengeluaran, kemudian membuat rancangan SPM apabila SPP yang telah diuji dinyatakan lengkap, dan menyerahkan SPM yang telah dibuat kepada pengguna anggaran untuk diotorisasi. Apabila SPP yang telah diuji dinyatakan tidak lengkap, PPKSKPD bertugas menerbitkan surat penolakan penerbitan SPM dan mengembalikannya kepada bendahara pengeluaran; dan (2) Pengguna anggaran yang kemudian bertugas untuk mengotorisasi dan menerbitkan SPM kemudian menyerahkannya kepada BUD dan juga bertugas untuk mengotorisasi surat penolakan penerbitan SPM yang diberikan PPK-SKPD apabila SPP yang telah diuji dinyatakan tidak lengkap.

Evaluasi prosedur penerbitan SP2D. SP2D diterbitkan berdasarkan SPM yang diserahkan oleh pengguna anggaran. Prosedur penerbitan surat perintah pencairan dana yang dilaksanakan oleh Dinas Perindustrian dan Perdagangan Daerah Provinsi Sulawesi Utara sudah sesuai dengan Permendagri Nomor 21 tahun 2011, dengan pihak-pihak yang terkait: (1) Pengguna Anggaran yang bertugas untuk mengotorisasi dan menerbitkan SPM dan mengajukannya kepada BUD dan juga bertugas untuk menerima dokumen SP2D yang diterbitkan oleh BUD dan menyerahkannya kepada bendahara pengeluaran; dan (2) Kuasa BUD yang bertugas untuk meneliti SPM yang diajukan oleh pengguna anggaran, menerbitkan SP2D apabila SPM yang telah diteliti dinyatakan lengkap dan sah, kemudian mendistribusikan SP2D kepada SKPD melalui Pengguna anggaran juga menerbitkan surat penolakan penerbitan SP2D apabila SPM dinyatakan tidak lengkap.

Evaluasi prosedur penerbitan Surat Pertanggungjawaban. SPJ adalah dokumen yang menjelaskan penggunaan dari dana-dana yang dikelola oleh bendahara pengeluaran. Bendahara pengeluaran wajib mempertanggung jawabkan penggunaan atau pengelolaan uang yang menjadi tanggung jawabnya kepada kepala SKPD melalui PPK-SKPD. Pada prosedur ini Dinas Perindustrian dan Perdagangan Daerah Provinsi Sulawesi Utara menggunakan dokumen pendukung SPP-LS sebagai bukti pertanggungjawaban. Dokumen pendukung tersebut antara lain: nota, kwitansi, berita acara serah terima pekerjaan/barang, berita acara pemeriksaan hasil pekerjaan, dokumentasi, dan lain-lain. Prosedur surat pertanggungjawaban yang dilaksanakan oleh Dinas Perindustrian dan Perdagangan Daerah Provinsi Sulawesi Utara sudah sesuai dengan Permendagri Nomor 21 tahun 2011, dengan pihak yang terkait yaitu bendahara pengeluaran dan PPTK yang melakukan tugas untuk mengumpulkan kelengkapan dokumen pertanggungjawaban, serta PPK-SKPD yang bertugas untuk menguji kelengkapan dokumen pertanggungjawaban.

\section{Evaluasi kegiatan pengendalian}

1. Sistem dan prosedur akuntansi. Dalam hal ini sistem dan prosedur pengeluaran kas yang diterapkan pada Dinas Perindustrian dan Perdagangan Daerah Provinsi Sulawesi Utara sudah dilaksanakan dengan baik sesuai dengan peraturan yang berlaku.

2. Otorisasi. Menunjukkan ketentuan tentang orang atau pejabat yang bertanggungjawab mengotorisasi suatu transaksi yang terjadi. Otorisasi tersebut bisa berbentuk kewenangan dalam memberikan tanda tangan pada formulir dan dokumen, dan sudah diterapkan dengan baik oleh Dinas sesuai peraturan yang berlaku. 
3. Formulir, dokumen dan catatan. Setiap transaksi yang terjadi selalu harus didukung dengan bukti transaksi yang valid dan sah. Formulir dan dokumen transaksi yang digunakan antara lain: DPA-SKPD, SPD, SPP, SPM, SP2D, kuitansi, dan lain sebagainya.

4. Pemisahan tugas. Dimaksudkan untuk menghindari terjadinya kecurangan yaitu dengan melaksanakan suatu proses transaksi dengan tidak hanya ditangani oleh satu orang tetapi dilakukan pemisahan tugas secara tegas sesuai dengan deskripsi tugas pokok dan fungsi yang jelas. Pada Dinas Perindustrian dan Perdagangan Daerah Provinsi Sulawesi Utara, pemisahan tugas untuk prosedur pengeluaran kas telah diterapkan dengan baik. Dimana untuk proses pengeluaran kas dari mulai hingga akhir dilakukan tidak hanya oleh satu orang saja, tetapi melibatkan beberapa pihak.

\section{KESIMPULAN DAN SARAN}

\subsection{Kesimpulan}

Berdasarkan hasil penelitian, dapat disimpulkan bahwa:

a. Prosedur pengeluaran kas belanja langsung yang dilaksanakan di Dinas Perindustrian dan Perdagangan Daerah Provinsi Sulawesi Utara pada tahun 2019 terdiri atas: (1) Penerbitan Surat Penyediaan Dana; (2) Pengajuan Surat Permintaan Pembayaran; (3) Penerbitan Surat Perintah Membayar; (4) Penerbitan Surat Perintah Pencairan Dana; dan (5) Penerbitan Surat Pertanggungjawaban.

b. Prosedur pengeluaran kas belanja langsung yang dilaksanakan di Dinas Perindustrian dan Perdagangan Daerah Provinsi Sulawesi Utara pada tahun 2019 sesuai dengan Peraturan Menteri Dalam Negeri Nomor 21 Tahun 2011 tentang Pedoman Pengelolaan Keuangan Daerah.

\subsection{Saran}

Penerapan sistem dan prosedur pengeluaran kas belanja langsung pada Dinas Perindustrian dan Perdagangan Daerah Provinsi Sulawesi Utara sudah sesuai dengan peraturan yang berlaku, sebaiknya Dinas Perindustrian dan Perdagangan Daerah Provinsi Sulawesi Utara tetap mempertahankan kepatuhan terhadap peraturan tersebut.

\section{DAFTAR PUSTAKA}

Lasut, M., Morasa, J., \& Mawikere, L. M. (2017). Evaluasi pelaksanaan sistem akuntansi belanja pada Dinas Sosial Tenaga Kerja dan Transmigrasi Kabupaten Minahasa Selatan sesuai PP No 71 tahun 2010. Going Concern: Jurnal Riset Akuntansi, 12(2), 149-156. https://doi.org/10.32400/gc.12.2.17445.2017

Longdong, A. S. (2013). Evaluasi prosedur pengeluaran kas belanja langsung pada Dinas Kebersihan Kota Bitung. Jurnal EMBA: Jurnal Riset Ekonomi, Manajemen, Bisnis dan Akuntansi, 1(4), 383-392. https://doi.org/10.35794/emba.v1i4.2700

Mahmudi. (2016). Analisis laporan keuangan pemerintah daerah. Yogyakarta: Penerbit Sekolah Tinggi Ilmu Manajemen YKPN.

Mahsun, M. (2016). Pengukuran kinerja sektor publik. Yogyakarta: BPFE.

Mewengkang, J., Sabijono, H., \& Pangerapan, S. (2016). Analisis pencatatan dan pelaporan belanja langsung pada satuan kerja perangkat daerah (SKPD) di Kabupaten Bolaang Mongondow (Studi pada Dinas Kependudukan dan Catatan Sipil). Jurnal EMBA: Jurnal Riset Ekonomi, Manajemen, Bisnis dan Akuntansi, 4(1), 817-825. https://doi.org/10.35794/emba.v4i1.11809

Ointu, M. R., \& Budiarso, N. (2016). Evaluasi pelaksanaan sistem dan prosedur pengeluaran kas uang persediaan pada DPPKAD Kab. Bolaang Mongondow Selatan. Jurnal 
EMBA: Jurnal Riset Ekonomi, Manajemen, Bisnis dan Akuntansi, 4(3), 156-164. https://doi.org/10.35794/emba.v4i3.13662

Parayanti, E. (2015). Evaluasi sistem dan prosedur akuntansi belanja pada satuan kerja perangkat daerah Dinas Kesehatan Provinsi Sulawesi Utara. Jurnal EMBA: Jurnal Riset Ekonomi, Manajemen, Bisnis dan Akuntansi, 3(3), 608-618. https://doi.org/10.35794/emba.v3i3.9512

Peraturan Menteri Dalam Negeri Nomor 13 Tahun 2006 Tentang Pedoman Pengelolaan Keuangan Daerah.

Peraturan Menteri Dalam Negeri Nomor 21 Tahun 2011 Tentang Perubahan Kedua Atas Peraturan Menteri Dalam Negeri Nomor 13 Tahun 2006 Tentang Pedoman Pengelolaan Keuangan Daerah.

Peraturan Pemerintah Republik Indonesia Nomor 60 Tahun 2008 Tentang Sistem Pengendalian Intern Pemerintah.

Peraturan Pemerintah Republik Indonesia Nomor 71 Tahun 2010 Tentang Standar Akuntansi Pemerintahan.

Polii, B. F., \& Mawikere, L. (2015). Evaluasi efektivitas penerapan sistem akuntansi pengeluaran kas atas Uang Persediaan (UP) pada Dinas Pertanian dan Peternakan Provinsi Sulawesi Utara.Going Concern: Jurnal Riset Akuntansi, 10(2), 20-28. https://doi.org/10.32400/gc.10.2.8366.2015

Sadeli, L. (2016). Dasar-dasar akuntansi. Jakarta: Bumi Aksara.

Singgima, F., \& Pinatik, S. (2016). Evaluasi prosedur pengeluaran kas belanja langsung pada Dinas Pendidikan Provinsi Sulawesi Utara. Jurnal EMBA: Jurnal Riset Ekonomi, Manajemen, Bisnis dan Akuntansi, 4(1), 723-731. https://doi.org/10.35794/emba.v4i1.11775

Sujarweni, V. W. (2015). Akuntansi sektor publik. Yogyakarta: Pustaka Baru Press.

Wonggo, P. M., Affandi, D., \& Suwetja, I. G. (2017). Analisis sisem penatausahaan belanja langsung di Pemerintah Kabupaten Minahasa Selatan (Studi kasus pada Dinas Sosial Tenaga Kerja dan Transmigrasi).Going Concern: Jurnal Riset Akuntansi, 12(2), 157166. https://doi.org/10.32400/gc.12.2.17446.2017 